\title{
Kualitas Madu Lokal dari Beberapa Wilayah di Kabupaten Temanggung
}

\author{
The Local Honey Quality of Some Areas in Temanggung
}

\author{
Ni Putu Tasya Savitri ${ }^{1 *}$, Endah Dwi Hastuti ${ }^{2}$, Sri Widodo Agung Suedy ${ }^{2}$ \\ ${ }^{1}$ Program Studi Biologi, Departemen Biologi, Fakultas Sains dan Matematika, Universitas Diponegoro \\ ${ }^{2}$ Departemen Biologi, Fakultas Sains dan Matematika, Universitas Diponegoro \\ Jl. Prof. H. Soedharto, SH, Tembalang, Semarang \\ *Email: putu.tasyans@gmail.com
}

Diterima 28 Desember 2016/Disetujui 20 Februari 2017

\begin{abstract}
ABSTRAK
Kualitas madu yang baik harus memenuhi standar acuan yang ditetapkan pemerintah. Kualitas madu dapat dilihat dari kadar air, gula total, dan keasaman. Penelitian ini bertujuan untuk mengetahui kualitas madu lokal dari 5 desa di Kabupaten Temanggung. Preparasi uji kadar air dan gula total dengan metode refraktometri, serta kadar keasaman dengan metode titrasi asam-basa. Metode penentuan lokasi sampling penelitian menggunakan metode purposive sampling berdasarkan perbedaan wilayah geografi, yaitu madu randu dari Desa Nglorog, madu kaliandra dari Desa Kwadungan Jurang, madu randu dari Desa Kentengsari, madu karet dari Desa Medari, dan madu kopi dari Desa Rejosari. Parameter yang digunakan untuk nilai kadar air, gula total, dan keasaman mengacu pada standar yang ditetapkan pemerintah (SNI-2013). Analisis data kuantitatif kadar air, gula total, dan keasaman menggunakan Analysis of Variance (ANOVA) dan Duncan's Multiple Range Test (DMRT). Hasil penelitian menunjukkan bahwa wilayah geografi yang berbeda pengaruh nyata pada kadar air, gula total, dan keasaman madu yang diteliti. Kualitas madu terbaik ditemukan pada madu karet dari Desa Medari dengan kadar air 20,9\%, kadar gula total 77,5\%,dan kadar keasaman 34,59 ml $\mathrm{NaOH} / \mathrm{kg}$ dimana nilainya mendekati nilai Standar Nilai Indonesia (SNI-2013) untuk madu.
\end{abstract}

Kata kunci: madu, kadar air, kadar gula total, kadar keasaman

\begin{abstract}
The quality of honey must be qualified by the government's rules. The quality of honey can be measured with water content, total sugar, and acidity. This study aims to determine the quality of local honey from 5 villages in Temanggung Regency. Preparation for testing the water content and total sugar were done using refractometry method, and acidity was done using the acid-base titration method. The location of sampling was determined using purposive sampling method based on regional differences, there were Ceiba honey from Nglorog Village, Calliandra honey from Kwadungan Jurang Village, Ceiba honey from Kentengsari Village, Rubber honey from Medari Village, and Coffee honey from Rejosari Village. The parameter of water content, total sugar, and acidity standard refer to the government's rules for honey (SNI-2013). The quantitative data of water content, total sugar, and acidity were analyzed using Analysis of Variance (ANOVA) and continued with Duncan's Multiple Range Test (DMRT) in extent of 95\%. The result showed that the different geographic areas were affected significantly on water content, total sugar, and acidity in the honey sample. This suggest that the local honey from some areas at Temanggung Regency which is qualified as a good honey based on the government's rules (SNI-2013) is Rubber honey from Medari Village, with moisture content of $20.9 \%$, total sugar content of $77.5 \%$ and acidity $\mathrm{NaOH}$ of $34.59 \mathrm{ml} / \mathrm{kg}$.
\end{abstract}

Keywords : honey, water content, total sugar content, acidity 


\section{PENDAHULUAN}

Madu merupakan produk alamyang dihasilkan oleh lebah karena mengandung nutrisi yang baik. Beberapa kandungan gizi dalam madu antara lain asam amino, karbohidrat, protein, dan beberapa jenis vitamin serta mineral (Suriawiria, 2000). Madu digunakan untuk menghilangkan rasa lelah, menghaluskan kulit, dan pertumbuhan rambut (Murtidjo, 1991; Purbaya, 2002).

Madu berasal dari nektar yang diolah lebah untuk dijadikan sebagai pakan yang disimpan dalam sarang.Nektar adalah suatu senyawa kompleks yang dihasilkan oleh kelenjar "necterifier" tanaman dalam bentuk larutan gula yang bervariasi. Komponen utama dari nektar adalah sukrosa, fruktosa, dan glukosa serta zat-zat gula lainnya seperti maltosa, melibiosa, rafinosa, dan turunan karbohidrat lainnya (Suranto, 2004). Proses pengolahan nektar menjadi madu yang dihasilkan oleh lebah madu terdiri dari 2 proses menurut Nainggolan (1992), yaitu melalui proses kimia (cairan manis nektar diubah menjadi gula yang lebih sederhana, reaksi ini disebut invertase. Invertase berlangsung secara katalitik dengan bantuan enzim yang terdapat di dalam nektar dan air liur lebah) dan proses fisika (proses pengurangan kadar air dalam nektar yang telah mengalami proses kimia dengan membiarkan nektar terkena udara dan dilanjutkan dengan kepakan sayap oleh lebah pekerja dalam stup hingga lebahmadu menutup sel-sel madu dengan selapis malam (wax) pada saat kadar air madu dalam sel sudah mencapai $\pm 20 \%$ ).

Kualitas madu dapat dilihat dari beberapa uji kualitas madu seperti uji kadar air, gula total, dan keasaman.Menurut SNI (2004), madu yang dipanen harus memiliki kadar air di bawah $22 \%$ dan kadar keasaman dengan nilai maksimal $50 \mathrm{ml}$ $\mathrm{NaOH} / \mathrm{kg}$. Menurut U.S. Patent Application Publication (2011), standar mutu gula total pada madu berkisar antara $76-83^{\circ}$ Brix (Sarig et al., 2011).Pengujian terhadap kualitas madu dilakukan agar madu yang dikonsumsi masyarakat memiliki standar kualitas sesuai dengan standar yang ditetapkan oleh pemerintah.

Tinggi rendahnya kadar air dalam madu umumnya dipengaruhi oleh iklim, pengelolaan saat panen, dan jenis nektar yang dikumpulkan oleh lebah. Selain kadar air, kualitas madu dipengaruhi oleh kadar gula total dan keasaman. Gula pada madu didominasi oleh fruktosa dan glukosa (Gaman, 1992). Tinggi rendahnya kadar gula dipengaruhi oleh tingkat kadar air dan keasaman dalam madu. Sedangkan, tinggi rendahnya kadar keasaman dipengaruhi oleh tingkat kadar air dalam madu. Menurut Budiwijono (2008), tingginya kadar air dalam madu menyebabkan madu mudah terfermentasi oleh khamir dari genus Zygosaccharomyces. Khamir akan mendegradasi gula menjadi alkohol. Apabila alkohol bereaksi dengan oksigen, alkohol tersebut akan membentuk asam bebas seperti asam asetat dan asam oksalat yang dapat mempengaruhi kadar keasaman, rasa, dan aroma madu.

Kabupaten Temanggung adalah salah satu daerah produsen dan pasar penjualan madu. Madu yang dihasilkan antara lain madu kopi, madu karet, madu rambutan, madu kelengkeng, madu randu, dan madu kaliandra. Tono (2016, komunikasi pribadi) mengatakan bahwa jenis madu yang dipasarkan ditentukan oleh musim pembungaan yang berlangsung. Perbedaan wilayah dan vegetasi tanaman akan menentukan jenis madu yang dihasilkan.

Penelitian ini menggunakan madu lokal yang diambil dari 5 desa, yaitu Desa Nglorog, Desa Kwadungan Jurang, Desa Kentengsari, Desa Medari, dan Desa Rejosari. Pemilihan terhadap 5 desa ini berdasarkan oleh adanya perbedaan wilayah dan terdapatnya produsen penghasil madu berkualitas yang dikenal oleh warga sekitar. Ato (2016, komunikasi pribadi) mengatakan bahwa Desa Kwadungan Jurang, Kentengsari, dan Medari adalah desa dengan dataran tinggi dan didominasi oleh tanaman jagung, kaliandra, karet, dan randu. Yono (2016, komunikasi pribadi) menambahkan bahwa Desa Nglorog dan Rejosari merupakan desa yang termasuk dalam Kecamatan Pringsurat tetapi lokasi Desa Nglorog berada di dataran lebih tinggi dibandingkan Desa Rejosari. Kedua desa ini didominasi oleh tanaman kopi, randu, dan karet.

Beberapa madu lokal tersebut merupakan produk madu yang belum terstandarisasi. Beberapa produsen madu bahkan mengklaim bahwa madunya mempunyai ciri khas seperti madu randu, 
madu kaliandra, madu karet, dan madu kopi. Beberapa penelitian mengenai kualitas madu sudah dilakukan, diantaranya oleh Karim dkk (2015) tentang kualitas madu dari Desa Terasa, Sulawesi Selatan yang menunjukkan bahwa madu lokal asal Desa Terasa memiliki kadar air yang berkisar antara 21,01-28,34\%, kadar gula yang berkisar antara $70-80 \%$, dan kadar keasaman yang berkisar antara 13,59-38,57 meq/kg. Sedangkan, penelitian kualitas madu oleh Purnamasari dkk (2015) di Bandung menunjukkan bahwa madu pahit dan madu murni asal Bandung memiliki kadar gula berkisar antara 62,61-92,57\% dan kadar keasaman berkisar antara 30-55 ml NaOH/kg. Sementara itu, penelitian tentang kualitas madu belum pernah dilakukan pada madu yang dihasilkan para produsen di wilayah Kabupaten Temanggung.

Pengujian terhadap kualitas madu pada beberapa wilayah di Kabupaten Temanggung dapat menghapus keraguan konsumen untuk membeli madu karena saat ini informasi mengenai cara membedakan madu asli yang berkualitas dengan madu palsu yang tidak berkualitas sangat sedikit. Selain itu, pengujian ini dapat membantu dalam mengatasi kasus yang sering terjadi seperti pemberian label produk madu yang tidak sesuai atau error labelling (Vaughn, 2011). Oleh karena itu, penelitian ini penting dilakukan untuk mengetahui kualitas madu lokal yang akan dikonsumsi dan diperjualbelikan pada beberapa wilayah di Kabupaten Temanggung.

\section{METODE PENELITIAN}

\section{Tempat dan Waktu Penelitian}

Pengambilan sampel madu lokal Kabupaten Temanggung dilakukan di5 desa, yaitu Desa Nglorog, Desa Kwadungan Jurang, Desa Kentengsari, Desa Medari, dan Desa Rejosari. Analisis madu dilaksanakan di Laboratorium Biologi Dasar serta Laboratorium Biologi Struktur dan Fungsi Tumbuhan Departemen Biologi FSM Universitas Diponegoro.Penelitian dilaksanakan dari bulan Mei 2016 sampai dengan bulan September 2016.

\section{Bahan dan Alat}

Alat yang digunakan dalam penelitian adalah refraktometer madu portable RHB-92ATC, neraca analitik terkalibrasi dengan ketelitian $0,0000 \mathrm{~g}$ merek Adventurer Ohaus, erlenmeyer ukuran $250 \mathrm{ml}$ dan $1000 \mathrm{ml}$ merek Pyrex, statif, buret ukuran $50 \mathrm{ml}$, gelas ukur ukuran $100 \mathrm{ml}$, No.7101, hotplate dengan stirrer merek Labinco Model L-81, pipet tetes, dan kertas label.

Bahan yang digunakan dalam penelitian adalah madu lokal dari 5 desa di Kabupaten Temanggung. Bahan lainnya adalah $\mathrm{NaOH} 0,1 \mathrm{~N}$, indikator PP $1 \%$, dan akuades.

\section{Cara Kerja}

\section{Pengambilan Sampel}

Lokasi sampling penelitian di daerah Kabupaten Temanggung ditentukan dengan metode purposive sampling, yaitu Desa Nglorog, Desa Kwadungan Jurang, Desa Kentengsari, Desa Medari, dan Desa Rejosari.Pengambilan sampel madu lokal dilakukan dengan cara mengambil madu dalam bentuk kemasan (botol) dari 5 peternak lebah madu yang berbeda di beberapa wilayah Kabupaten Temanggung. Masing-masing wilayah diambil 3 botol, yaitu: madu randu dari Desa Nglorog, madu kaliandra dari Desa Kwadungan Jurang, madu randu dari Desa Kentengsari, madu karet dari Desa Medari, dan madu kopi dari Desa Rejosari.

\section{Uji Kadar Air}

Kadar air ditentukan dan diukur dengan menggunakan refraktometer madu. Cara menggunakan refraktometer madu adalah plat cahaya dibuka lalu madu diteteskan beberapa tetes hingga madu menutupi seluruh area biru. Hasilnya adalah nilai pada skala kadar air yang tertera pada view finder. Nilai kadar air dinyatakan dalam persen $(\%)$.

\section{Uji Kadar Gula Total}

Pembacaan nilai kadar gula total madu menggunakan alat refraktometer madu. Nilai 
dinyatakan dalam satuan brix.Derajat brix, juga dikenal sebagai ${ }^{\circ}$ Brix, Brix, \% Brix, yaitu unit pengukuran konsentrasi gula dari cairan. Suatu larutan memiliki satu derajat Brix (= $1 \%$ Brix) jika memiliki indeks bias yang sama sebagai larutan 1 g sukrosa dalam $100 \mathrm{~g}$ larutan air sukrosa (Krüss, 2016).Cara menggunakan refraktometer madu sama seperti pada kadar air, perbedaannya adalah hasil yang diperoleh tertera pada skala nilai kadar gula total

\section{Uji Kadar Keasaman}

Pengujian kadar keasaman berdasarkan Anonim (2013), yaitu :

1. Madu ditimbang sebanyak $10 \mathrm{~g}$, lalu dimasukkan ke dalam erlenmeyer $250 \mathrm{ml}$ kemudian dilarutkan dengan $75 \mathrm{ml}$ air suling dan ditambahkan 4-5 tetes indikator PP;

2. Larutan tersebut dititrasi dengan larutan $\mathrm{NaOH} 0,1 \mathrm{~N}$ sampai titik akhir yang tetap selama 10 detik;

3. Volume $\mathrm{NaOH} \mathrm{0,1} \mathrm{N}$ yang digunakan untuk titrasi dicatat;

4. Kadar keasaman dalam madu dihitung dengan menggunakan rumus :

\section{Keasaman $(m l ~ N ~ N a O H / k g)=a \times b / c \times 1000$}

Keterangan :

a) $a$ adalah volume $\mathrm{NaOH} \quad 0,1 \quad \mathrm{~N}$ yang digunakan dalam titrasi, dinyatakan dalam $\mathrm{ml}$;

b) $b$ adalah normalitas $\mathrm{NaOH} 0,1 \mathrm{~N}$;

c) $c$ adalah bobot contoh, dinyatakan dalam gram.

\section{HASIL DAN PEMBAHASAN}

Penelitian ini bertujuan untuk mengetahui kualitas madu lokal dari 5 desa di Kabupaten Temanggung, yaitu Desa Nglorog, Desa Kwadungan Jurang, Desa Kentengsari, Desa Medari, dan Desa Rejosari. Hasil penelitian dari uji kadar air, gula total, dan keasaman dijelaskan sebagai berikut.

\section{Kadar Air}

Hasil uji Analysis of Variance (ANOVA) menunjukkan bahwa wilayah yang berbeda memiliki pengaruh nyata terhadap kadar air pada sampel madu. Hasil uji lanjut Duncan's Multiple Range Test (DMRT) dengan taraf kepercayaan 95\% kadar air dalam madu pada wilayah yang berbeda disajikan dalam Tabel 1 .

Tabel 1. Rata-rata nilai kadar air dalam madu pada wilayah yang berbeda

\begin{tabular}{cc}
\hline Wilayah & Kadar Air (\%) \\
\hline Nglorog & $30,5^{\mathrm{b}}$ \\
Kwadungan Jurang & $25,4^{\mathrm{c}}$ \\
Kentengsari & $32,8^{\mathrm{a}}$ \\
Medari & $20,9^{\mathrm{e}}$ \\
Rejosari & $22,4^{\mathrm{d}}$ \\
\hline
\end{tabular}

Keterangan: Angka yang diikuti oleh huruf yang berbeda menunjukkan pengaruh nyata berdasarkan uji lanjut Duncan pada taraf kepercayaan $95 \%$.

Hasil penelitian menunjukkan bahwa madu randu dari Desa Kentengsari memiliki kadar air tertinggi dan melebihi standar yang ditetapkan dalam SNI tahun 2013 dengan nilai sebesar 32,8\%. Hal ini disebabkan oleh pengaruh suhu lingkungan pada wilayah Kabupaten Temanggung yang bersuhu dingin sehingga menyebabkan tingkat kelembaban udara pada lingkungan tersebut meningkat dan menyebabkan madu mudah mengalami proses pencairan.

Madu randu dari Desa Nglorog memiliki kadar air yang tidak jauh berbeda dari madu randu dari Desa Kentengsari, yaitu 30,5\%. Hal ini menunjukkan bahwa selain karena pengaruh dari keadaaan lingkungan, tekstur madu randu yang cenderung encer membuktikan bahwa madu tersebut memiliki kadar air yang tinggi. Tori (2016, komunikasi pribadi) menyatakan bahwa suhu lingkungan di wilayah Temanggung yang dingin menyebabkan madu randu lebih cepat menjadi encer karena kadar airnya cepat bertambah akibat penguapan yang terjadi dalam madu tersebut. 
Madu kaliandra dari Desa Kwadungan Jurang dan madu kopi dari Desa Rejosari juga memiliki kadar air yang melebihi standar yang ditetapkan dalam SNI tahun 2013. Madu kaliandra dari Desa Kwadungan Jurang memiliki kadar air sebesar 25,4\%. Hal ini disebabkan oleh waktu panen madu yang tidak tepat. Proses panen madu dilakukan saat mendekati musim penghujan, sehingga menyebabkan madu yang dihasilkan memiliki kadar air tinggi. Hal ini sesuai dengan pernyataan Yono (2016, komunikasi pribadi) bahwa madu tersebut dipanen sebelum masuk periode musim hujan sehingga kemungkinan madu tersebut memiliki kandungan air yang tinggi.

Madu kopi dari Desa Rejosari memiliki kadar air yang nilainya sedikit melebihi standar yang ditetapkan dalam SNI tahun 2013, yaitu $22,4 \%$. Hal ini disebabkan karena madu tersebut sudah lama disimpan walaupun teksturnya tampak tidak terlalu encer dan warnanya pekat. Waktu panen madu yang tepat menyebabkan warna madunya pekat tetapi jika madu disimpan terlalu lama ditempat yang memiliki kelembaban tinggi maka kadar airnya akan bertambah tinggi. Hal ini sesuai dengan pernyataan Tono (2016, komunikasi pribadi) bahwa madu dijadikan stok untuk diperdagangkan saat sedang tidak musim panen sehingga madu akan lama disimpan dan menyebabkan madunya menjadi lebih cair.

Sementara itu, madu karet dari Desa Medari memiliki kadar air terendah dan nilainya memenuhi standar yang ditetapkan dalam SNI tahun 2013, yaitu 20,9\%. Suhu lingkungan yang rendah membuat madu lebih mudah mengalami pencairan tetapi karena tekstur madu karet yang sangat kental maka madu tersebut lebih mudah bertahan jika disimpan dalam jangka waktu yang lama. Madu tersebut tidak mudah mengalami fermentasi karena kadar airnya sedikit. Hal tersebut menyebabkan mikroba tidak mudah berkembang dan tumbuh. Kadar air yang rendah pada madu ini menunjukkan bahwa madu tersebut berkualitas dan baik untuk dikonsumsi. Ato (2016, komunikasi pribadi) mengatakan bahwa madu karet tidak mudah mengalami fermentasi karena kandungan airnya sedikit sehingga madu tersebut bisa disimpan dalam jangka waktu yang lama.
Tinggi rendahnya kadar air dalam sampel madu yang diteliti dapat disebabkan oleh pengaruh suhu lingkungan serta cara produksi dan waktu panen madu. Suhu wilayah Kabupaten Temanggung dengan kisaran antara $20-30^{\circ} \mathrm{C}$ yang tercatat pada data BPS Kabupaten Temanggung (2015) menunjukkan bahwa wilayah tersebut pada umumnya berhawa dingin dan sejuk. Suhu lingkungan yang tinggi dapat menyebabkan madu mudah mencair. Hal ini sesuai dengan pernyataan Sihombing (2005), bahwa madu yang disimpan pada suhu yang rendah akan lebih mudah mengalami pencairan. Ajeng dkk (2014) menyatakan bahwa kadar air tinggi disebabkan oleh waktu panen yang terlalu dini, yaitu sebagian besar sarang masih belum tertutup lilin sehingga tingkat kematangan madu yang dihasilkan belum maksimal. Sementara itu, jika kadar air dalam madu tersebut rendah, maka madu akan terhindar dari kerusakan untuk jangka waktu penyimpanan yang relatif lama serta dapat meminimalisir keberadaan mikroba dalam madu (Hilmanto, 2010).

\section{Kadar Gula Total}

Hasil uji Analysis of Variance (ANOVA) menunjukkan bahwa wilayah yang berbeda memiliki pengaruh nyata pada kadar gula total pada sampel madu. Hasil uji lanjut Duncan's Multiple Range Test (DMRT) dengan taraf kepercayaan $95 \%$ kadar gula total dalam sampel madu disajikan dalam Tabel 2.

Tabel 2. Rata-rata nilai kadar gula total dalam madu pada wilayah yang berbeda

\begin{tabular}{cc}
\hline Wilayah & Kadar Gula Total (\%) \\
\hline Nglorog & $69,5^{\mathrm{d}}$ \\
Kwadungan Jurang & $72,8^{\mathrm{c}}$ \\
Kentengsari & $67,2^{\mathrm{e}}$ \\
Medari & $77,5^{\mathrm{a}}$ \\
Rejosari & $75,9^{\mathrm{b}}$ \\
\hline
\end{tabular}

Keterangan: Angka yang diikuti oleh huruf yang berbeda menunjukkan pengaruh nyata berdasarkan uji lanjut Duncan pada taraf kepercayaan $95 \%$. 
Hasil penelitian menunjukkan bahwa madu karet dari Desa Medari memiliki kadar gula total yang memenuhi standar yang ditetapkan dalam U.S. Patent Application Publication tahun 2011, yaitu $77,5 \%$. Hal ini disebabkan karena tingginya kandungan gula dalam nektar pada tanaman karet sehingga madu karet mudah mengalami pembekuan jika disimpan dalam waktu yang lama. Gula dominan yang terkandung dalam madu karet adalah glukosa sehingga madunya akan memiliki rasa yang jauh lebih manis dibandingkan dengan jenis madu lainnya. Hal ini diperkuat oleh Tono (2016, komunikasi pribadi) bahwa jika madu karet disimpan dalam suhu lingkungan yang rendah maka madu karet menjadi lebih mudah mengkristal. Jenis gula berupa glukosa merupakan jenis gula dominan yang menyebabkan madu karet mudah mengkristal.

Sementara itu, madu randu dari Desa Nglorog dan Kentengsari, madu kaliandra dari Desa Kwadungan Jurang, dan madu kopi dari Desa Rejosari memiliki kadar gula total yang tidak memenuhi standar yang ditetapkan dalam U.S. Patent Application Publication tahun 2011. Madu randu dari Desa Nglorog memiliki kadar gula total sebesar 69,5\%. Madu randu dari Desa Kentengsari memiliki kadar gula total yang nilainya tidak jauh berbeda, yaitu $67,2 \%$. Madu tersebut memiliki kadar gula total terendah dibandingkan dengan kadar gula total pada seluruh sampel. Hal ini disebabkan karena tingginya kadar air dan keasaman pada madu randu yang menyebabkan kadar gula totalnya menjadi rendah. Tekstur dari madu randu yang cenderung encer dan warna madu yang tidak pekat menunjukkan bahwa madu tersebut memiliki kadar gula yang rendah akibat tingginya kadar air yang menyebabkan proses fermentasi mudah terjadi. Hal ini sesuai dengan pernyataan Tori (2016, komunikasi pribadi) bahwa madu randu memiliki sedikit rasa manis karena madunya mudah mengalami fermentasi sehingga rasanya cenderung lebih asam dan pahit.

Madu kaliandra dari Desa Kwadungan Jurang memiliki kadar gula total sebesar $72,8 \%$. Hal ini disebabkan oleh waktu panen madu yang tidak tepat sehingga menyebabkan madu menjadi kurang matang dan kandungan gula didalamnya cenderung sedikit. Tekstur madu yang cenderung encer dan berwarna kuning pucat menunjukkan bahwa madu tersebut memiliki kadar gula yang sedikit. Hal ini berbeda dengan pernyataan Yono (2016, komunikasi pribadi) bahwa madu tersebut rasanya akan menjadi semakin manis karena madu kaliandra memiliki tekstur yang akan menjadi semakin kental dan semakin manis jika disimpan lebih lama walaupun dipanen saat mendekati musim hujan.

Madu kopi dari Desa Rejosari memiliki kadar gula total yang hampir mendekati standar yang ditetapkan dalam U.S. Patent Application Publication tahun 2011, yaitu 75,9\%. Hal ini disebabkan karena lamanya penyimpanan dari madu tersebut sehingga kandungan gula didalamnya menjadi berkurang. Madu kopi memiliki tekstur yang cenderung sedikit lebih encer menunjukkan bahwa kadar air didalamnya tinggi sehingga kadar gulanya menjadi lebih rendah. Hal ini sesuai dengan pernyataan Tono (2016, komunikasi pribadi) bahwa madu kopi cenderung encer tetapi rasanya tidak terlalu asam sehingga kadar gula didalamnya masih banyak walaupun rasa manisnya tidak tinggi seperti madu karet.

Kadar gula total secara umum dipengaruhi oleh kadar air dan keasaman. Chasanah (2001) mengatakan bahwa kadar air tinggi pada madu akan merangsang aktivitas khamir untuk tumbuh dan berkembang sehingga khamir dalam madu akan mendegradasi gula (glukosa dan fruktosa) menjadi alkohol dan $\mathrm{CO}_{2}$ yang menyebabkan madu menjadi tambah asam sehingga kandungan glukosa dan fruktosa dalam madu menjadi semakin rendah.

\section{Kadar Keasaman}

Hasil uji Analysis of Variance (ANOVA) menunjukkan bahwa kadar keasaman pada sampel madu memiliki pengaruh nyata pada wilayah yang berbeda. Hasil uji lanjut Duncan's Multiple Range Test (DMRT) dengan taraf kepercayaan 95\% kadar keasaman madu disajikan dalam Tabel 3.

Hasil penelitian menunjukkan bahwa madu randu dari Desa Nglorog memiliki kadar keasaman tertinggi dan melebihi SNI tahun 2013, yaitu 67,96 $\mathrm{ml} \mathrm{NaOH} / \mathrm{kg}$, sedangkan, madu randu dari Desa 
Kentengsari memiliki kadar keasaman sebesar $64,2 \mathrm{ml} \mathrm{NaOH} / \mathrm{kg}$. Hal ini disebabkan oleh tekstur madu randu yang cenderung encer sehingga kadar air dalam madu tersebut menjadi tinggi yang mengakibatkan proses fermentasi mudah terjadi dan mempengaruhi tingkat keasaman dalam madu tersebut. Semakin lama disimpan maka rasa madu randu akan menjadi semakin asam. Hal ini sesuai dengan pernyataan Hadi (2016, komunikasi pribadi) bahwa madu randu memiliki rasa yang asam dan pahit karena madunya mudah mengalami fermentasi sehingga rasanya akan menjadi lebih asam. Tori (2016, komunikasi pribadi) menambahkan bahwa lama penyimpanan terhadap madu randu juga mempengaruhi tingkat keasaman madu tersebut.

Tabel 3. Rata-rata nilai kadar keasaman dalm madu pada wilayah yang berbeda

\begin{tabular}{cc}
\hline Wilayah & $\begin{array}{c}\text { Kadar Keasaman } \\
(\mathrm{ml} \mathrm{NaOH} / \mathrm{kg})\end{array}$ \\
\hline Nglorog & $67,96^{\mathrm{a}}$ \\
Kwadungan Jurang & $43,27^{\mathrm{d}}$ \\
Kentengsari & $64,20^{\mathrm{b}}$ \\
Medari & $34,59^{\mathrm{e}}$ \\
Rejosati & $45,67^{\mathrm{c}}$ \\
\hline
\end{tabular}

Keterangan: Angka yang diikuti oleh huruf yang berbeda menunjukkan pengaruh nyata berdasarkan uji lanjut Duncan pada taraf kepercayaan $95 \%$.

Sementara itu, madu kaliandra dari Desa Kwadungan Jurang, madu karet dari Desa Medari, dan madu kopi dari Desa Rejosari memiliki kadar keasaman yang memenuhi standar yang ditetapkan dalam SNI tahun 2013. Madu kaliandra dari Desa Kwadungan Jurang memiliki kadar keasaman sebanyak 43,27 ml NaOH/kg. Hal ini disebabkan oleh madu tersebut belum lama mengalami proses fermentasi sehingga asam bebas belum banyak bermunculan walaupun kadar air pada madu tersebut tinggi akibat waktu panen yang tidak tepat. Fermentasi yang belum lama terjadi dapat diketahui dari keberadaan gas alkohol yang jumlahnya sedikit. Hal ini sesuai dengan pernyataan Yono (2016, komunikasi pribadi) bahwa madu tersebut dipanen dalam kondisi madu yang agak encer tetapi rasa manis dalam madu masih dominan sehingga belum timbul rasa asam didalamnya.

Madu kopi dari Desa Rejosari memiliki kadar keasaman yang hampir mendekati standar yang ditetapkan dalam SNI tahun 2013, yaitu $47,67 \mathrm{ml} \mathrm{NaOH} / \mathrm{kg}$. Hal ini disebabkan oleh kadar air yang tinggi pada madu tersebut sehingga proses fermentasi akan lebih mudah berlangsung dan mempengaruhi kadar keasamannya. Madu ini masih memiliki kadar keasaman wajar tetapi apabila disimpan lebih lama maka madu tersebut akan memiliki bau alkohol yang semakin meningkat akibat proses fermentasi. Hal ini sesuai dengan pernyataan Tono (2016, komunikasi pribadi) bahwa madu tersebut sudah lama disimpan sehingga ada kemungkinan bahwa rasa madunya akan lebih asam akibat meningkatnya gas alkohol dari hasil fermentasi dalam madu tersebut.

Madu karet dari Desa Medari memiliki kadar keasaman terendah dibandingkan dengan kadar keasaman pada seluruh sampel madu yang diteliti, yaitu $34,59 \mathrm{ml} \mathrm{NaOH} / \mathrm{kg}$. Hal ini disebabkan karena madu karet memiliki tekstur madu yang kental dan mudah mengalami pembekuan sehingga menunjukkan bahwa mikroba pembusuk yang mempengaruhi keasaman madu tidak mudah tumbuh. Ato (2016, komunikasi pribadi) mengatakan bahwa madu karet tidak mudah mengalami fermentasi karena kadar airnya rendah sehingga madu tersebut tidak memiliki rasa asam.

Kadar keasaman madu sangat dipengaruhi oleh kadar air yang terkandung didalamnya. Budiwijono (2008) mengatakan bahwa kadar air madu yang rendah menyebabkan mikroba pembusuk tidak dapat hidup. Rendahnya kadar air juga mempengaruhi keberadaan khamir yang menyebabkan terjadinya fermentasi. Semakin tinggi nilai $\mathrm{ml} \mathrm{NaOH} / \mathrm{kg}$ dalam madu maka tingkat keasaman semakin tinggi. Hal ini sesuai dengan pernyataan Dewi (2013) bahwa madu memiliki sifat higroskopis yang menyebabkan kadar air meningkat karena madu merupakan larutan jenuh gula dengan gugus $\mathrm{OH}^{-}$bebas yang reaktif. 


\section{KESIMPULAN}

Kualitas madu berbeda pada masing-masing wilayah. Terdapat variasi kadar air, gula total, dan keasaman dari madu lokal Kabupaten Temanggung. Kadar air pada sampel madu yang diteliti berkisar antara 20,9-32,8\%.Kadar gula total pada sampel madu yang diteliti berkisar antara 67,2-77,5\% Kadar keasaman pada sampel madu yang diteliti berkisar antara 34,59-67,96 ml $\mathrm{NaOH} / \mathrm{kg}$. Madu dengan nilai uji kualitas mendekati SNI dan U.S. Patent Application Publication adalah madu karet dari Desa Medari.

\section{DAFTAR PUSTAKA}

Anonim. 2004. Madu. Badan Standarisasi Nasional. SNI 01-3545-2004. ICS 67.180.10.

. 2013. Madu. Badan Standarisas Nasional. SNI 01-3545-2013. ICS 67.180.10.

2015. Data Strategis Kabupaten Temanggung.www.temanggungkab.bps.go.i d. Diakses pada 17 Juli 2016.

Ajeng, P., S. Minarti dan M. Yunus. 2014. Perbandingan Kadar Air dan Aktivitas Enzim Diastase Madu Lebah Apis mellifera di Kawasan Penggembalaan Mangga (Mangifera indica) dan Kawasan Penggembalaan Karet (Hevea brasilliensis). Skripsi. Universitas Brawijaya. Malang.

Budiwijono, T. 2008. Evaluasi Kadar Gula Pereduksi, Derajat Keasaman dan Identifikasi Enzim pada Madu yang dipanaskan dengan Oven Udara Kering SistemKonveksi.http://publikasi.umm.ac.id. Diakses pada 17 Desember 2015.

Chasanah, N. 2001. Kadar Dekstrosa, Levulosa, Maltosa, serta Fruktosa Madu Segar dan Madu Bubuk dengan Bahan Pengisi Campuran Gum Arab dan Dekstin. Skripsi. Fakultas Peternakan, Institut Pertanian, Bogor.

Dewi. R. D.A. dan Susanto. H. S. 2013. Pembuatan Lempok Pisang (Kajian Jenis
Pisang dan Konsentrasi Madu). Jurnal Pangan dan Agroindustri. 1(1): 101-114

Gaman. M. 1992. Ilmu Pangan, Penghantar Ilmu Pangan, Nutrisi dan Mikrobiologi. Edisi II. Yogyakarta: Gadjah Mada University Press.

Hilmanto, R. 2010. Analisis Paket Teknologi Lokal Dalam Pengelolaan Produksi Madu Organik Untuk Pasar Global Dan Industri. Jurnal Ilmu Pertanian Indonesia. ISSN 0853-4217.

Karim, F.F., Noor, A dan H. Natsir 2015. Analisis Mineral Esensial (Vanadium, Kobalt dan Nikel) dan Uji Bio-Fisika Kimia Pada Madu Asal Desa Terasa Sinjai. Skripsi. Universitas Hasanuddin. Makassar.

Krüss. 2016. Refractometers: Professional Solutions For Every Field of Application. www.kruess.com. Diakses pada tanggal 23 November 2016.

Murtidjo, B.A. 1991. Memelihara Lebah Madu. Penerbit Kanisius. Yogyakarta.

Nainggolan, S. 1992. Pemeriksaan Kandungan Kimia Madu dari Hasil Perolehan Lebah Pemeliharaan dan Lebah Hutan. Lembaga Penelitian Universitas Sumatera Utara. Medan.

Purbaya, J. R. 2002. Mengenal dan Memanfaatkan Khasiat Madu Alami. Penerbit Pinonir Jaya, Bandung.

Purnamasari, N., Aprilia, H dan Sukanta. 2015. Pembandingan Parameter Fisikokimia Madu Pahit (Aktivitas Enzim Diastase, Gula Pereduksi (Glukosa), Keasaman, Cemaran Abu dan Arsen) dengan Madu Manis Murni Prosiding Penelitian SPeSIA (Sivitas Akademika Kesehatan dan Farmasi) FMIPA Universitas Islam Bandung. Bandung.

Sarig, Y., Sarig, O and E. Siegler. 2011. U.S. Patent Application Publication: SEMISOLID HONEY-BASEDPRODUCTS. United States.

Sihombing D. T. H. 2005. Ilmu Ternak Lebah Madu. Yogyakarta: Gadjah Mada University Press. 
Suranto, A. 2004. Khasiat dan Manfaat Madu Herbal. Jakarta: Agro Media Pustaka

Suriawiria, H. U. 2000. Madu untuk Kesehatan, Kebugaran, dan Kecantikan. Jakarta: Papas Sinar Sinanti.

Vaughan, J. G. 2011. The Structure and Utilization of Seed. Chapman and Hall. London. Schan Co (PVT) Ltd. Ram Nagan New. Page 440. 